Article

\title{
Influence of Age on Stress Responses of White Seabream to Amyloodiniosis
}

\author{
Márcio Moreira ${ }^{1,2}$, Anaísa Cordeiro-Silva ${ }^{1}$, Marisa Barata ${ }^{1}$, Pedro Pousão-Ferreira ${ }^{1}(\mathbb{D}$ and \\ Florbela Soares ${ }^{1, *}$ \\ 1 IPMA-Portuguese Institute for the Ocean and Atmosphere, EPPO-Aquaculture Research Station, \\ 8700-305 Olhão, Portugal; marcio.moreira@ipma.pt (M.M.); anaisa.silva@ipma.pt (A.C.-S.); \\ mbarata@ipma.pt (M.B.); pedro.pousao@ipma.pt (P.P.-F.) \\ 2 CCMAR, Centre of Marine Sciences, University of Algarve, 8005-139 Faro, Portugal \\ * Correspondence: fsoares@ipma.pt
}

Received: 24 February 2019; Accepted: 4 April 2019; Published: 8 April 2019

\begin{abstract}
Amyloodiniosis is a disease that represents a major bottleneck for semi-intensive aquaculture, especially in Southern Europe. The inefficacy of many of the treatments for this disease on marine fish produced in semi-intensive aquaculture has led to a new welfare approach to amyloodiniosis. There is already some knowledge of several welfare issues that lead to amyloodiniosis as well as the stress, physiological, and immunological responses to the parasite by the host, but no work is available about the influence of fish age on the progression of amyloodiniosis. The objective of this work was to determine if stress, hematological, and histopathological responses are age dependent. For that purpose, we determined the mortality rate, histopathological lesions, hematological indexes, and stress responses (cortisol, glucose, lactate, and total protein) in "Small" (total weight: $50 \pm 5.1 \mathrm{~g}$, age: 273 days after eclosion (DAE)) and "Big" (total weight: $101.3 \pm 10.4 \mathrm{~g}$, age: 571 DAE) white seabream (Diplodus sargus) subjected to an Amyloodinium ocellatum infestation (8000 dinospores $\mathrm{mL}^{-1}$ ) during a $24-\mathrm{h}$ period. The results demonstrated a strong stress response to $A$. ocellatum, with marked differences in histopathological alterations, glucose levels, and some hematological indexes between the fish of the two treatments. This work elucidates the need to take in account the size and age of the fish in the development and establishment of adequate mitigating measures and treatment protocols for amyloodiniosis.
\end{abstract}

Keywords: aquaculture; Amyloodinium ocellatum; age; physiological response; hematology; histopathology; welfare

\section{Introduction}

Amyloodiniosis is a disease that represents a major bottleneck for semi-intensive aquaculture, especially in Southern Europe [1]. It is caused by one of the most common and important parasitic dinoflagellates in marine fish, Amyloodinium ocellatum (Brown). This parasite can potentially affect almost all fish species living within its ecological range (temperature: $16-30{ }^{\circ} \mathrm{C}$; salinity: $10-60 \mathrm{psu}$ ) [2] A. ocellatum has a triphasic lifecycle with a parasitic trophont, a reproductive encysted tomont, and a free-motile infective dinospore stage [3]. It is considered one of the most consequential pathogens for marine fish, causing serious morbidity and mortality (around 100\%) in brackish and marine warmwater fish in different aquaculture facilities worldwide [2]. The affected producers can suffer severe economic impacts, as demonstrated in reported cases of amyloodiniosis in a milkfish (Chanos chanos) hatchery in 2004 [4] or in Nile tilapia (Oreochromis mossambicus) in the Salton Sea [5], where total losses reached US\$20,000 and US\$6-77 million, respectively [6]. The open design of many aquaculture systems also allows the easy dissemination of this parasite to new places in their ecological range, 
where they find ideal conditions to cause disease outbreaks [7,8]. A. ocellatum outbreaks develop extremely fast and, at the time of its detection, contaminated fish no longer respond to treatment, resulting in 100\% mortality in a few days [1]. The clinical signs of this disease are changes in fish behavior, with jerky movements, swimming at the water surface, and decreased appetite [1]. These may also include increased respiratory rate and gathering at the surface or in areas with higher dissolved oxygen concentrations.

There are several treatments available for amyloodiniosis, especially for the motile infective dinospore $[9,10]$, since the parasitic and encapsulated state of trophont and tomont are difficult to treat and eradicate [1]. These treatments can range from the most classical ones, such as formaldehyde [11]; copper sulphate $[1,10,12,13]$, which can be done in combination with freshwater treatment [14]; or hydrogen peroxide $[15,16]$, to the more atypical ones, such as the addition of larval brine shrimp (Artemia salina) to the tank to prey on A. ocellatum dinospores [17]. However, most of these treatments are highly ineffective or unpractical for earthen pond semi-intensive aquaculture, which is the most common type of aquaculture facility in Southern Europe [1]. This treatment problem, considering that this is a common and highly consequential disease for producers and that naturally occurring A. ocellatum blooms have already been detected $[18,19]$, led us to make a new and more holistic approach to this disease.

One of the more promising approaches to amyloodiniosis is to consider that it is not only a health and epidemiological problem, which is a very reductionistic approach to the disease, but also a welfare problem [20].

A disease as a welfare problem is a very special case because it is caused by several other welfare issues, such as inadequate aquaculture protocols [21], poor water quality [22], nutritional imbalances [23], physical disturbances (e.g., transport [24] or handling [25]), stocking densities [26], or social behaviors [27] that can increase the probability of disease outbreaks. However, the disease is, by itself, a welfare problem and can also cause other welfare problems, such as a decrease in water quality due to fish death and decay as well as secondary effects of fish treatment [28]. All of these preand post-disease welfare issues can cause chronic stress [24] and immunocompetence loss in fish [29].

Regarding amyloodiniosis, some work has already been done on controlling some of the welfare issues that can cause this disease. We already know the temperature, oxygen, and salinity conditions that favor amyloodiniosis outbreak [30-32]. Previous works have already established the water quality parameters, fish stock density, and water renewal rate in fish production ponds to avoid A. ocellatum infestation in seabream [33]; the consequences for water quality due to fish death and decay [16]; and routine hygiene procedures to avoid water quality problems and reinfestation during an amyloodiniosis outbreak [1]. There are also works that state that fish mortality in an amyloodiniosis outbreak can be caused by anoxia, which is associated with serious gill hyperplasia, inflammation, hemorrhage, and necrosis, in heavy infestations [9] or osmoregulatory impairment and secondary microbial infections due to severe epithelial damage in some lethal cases, which is associated with apparently mild infestations [31]. Further, the immunological [34-39], stress, and metabolic responses of some fish species to A. ocellatum [40-44] have also been studied.

However, there have been no studies on the effect of age on the responses or mortality of fishes to an $A$. ocellatum infestation.

So, the objective of this work was to analyze the stress and hematological responses and mortality of white seabream (Diplodus sargus) from different ages when exposed to an A. ocellatum infestation.

\section{Results}

\subsection{Gill Analysis}

White seabream gill wet mounts from Small and Big treatments are presented in Figure 1. 


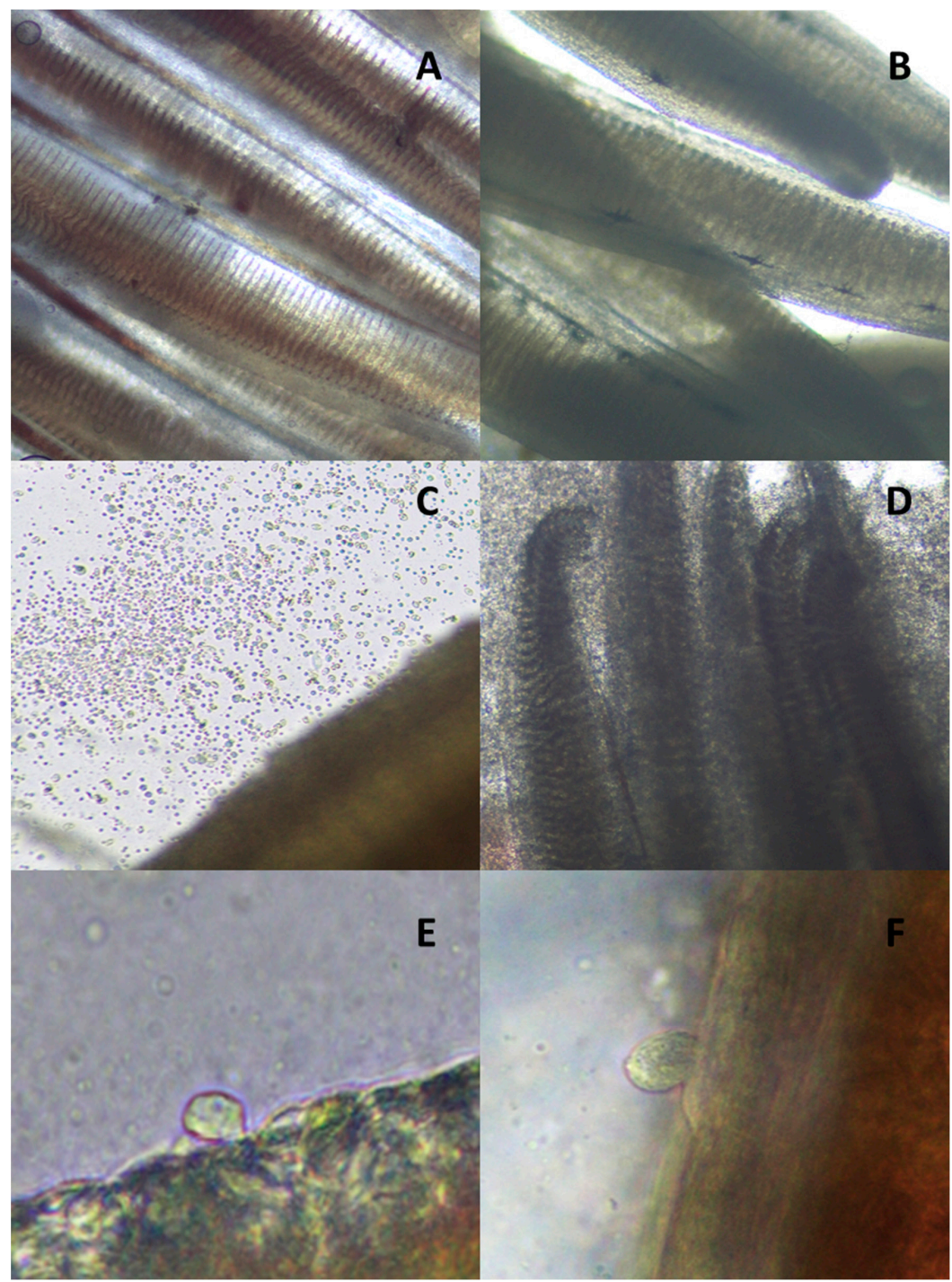

Figure 1. Wet mount of white seabream (Diplodus sargus) gills from "Small" and "Big" experimental groups: (A) gill from Small treatment at $0 \mathrm{~h}(100 \times)$; (B) gill from Big treatment at $0 \mathrm{~h}(100 \times)$; (C) Small treatment at $5 \mathrm{~h}$, presenting several Amyloodinium ocellatum dinospores near the gill (400×); (D) Big treatment at $24 \mathrm{~h}$, presenting several $A$. ocellatum dinospores near the gill and a great amount of mucus $(400 \times)$; and A. ocellatum trophonts in gill from Small treatment (E) and Big treatment (F) at $5 \mathrm{~h}$ of infestation.

We observed that there were no parasites in the gills of both treatments at $0 \mathrm{~h}$ of white seabream A. ocellatum infestation, which validated the history of no parasitological infestation of the fishes (see Figure 1A,B).

Five hours after infestation, we observed the fixation of $A$. ocellatum dinospores and their transformation to trophonts in both treatments (see Figure 1C,E,F). However, the A. ocellatum trophont counts revealed that the Small treatment had more parasite fixation (more than 500 parasites per gill arch) than the Big treatment (between 250 and 300 parasites per gill arch).

Twenty-four hours after infestation, we also observed the secretion of massive quantities of mucus by the gill in the Big treatment (see Figure 1D). The parasite count was $155 \pm 5$ parasites for the gill arch, which was lower than the parasite load observed after $5 \mathrm{~h}$ of infestation for this treatment. The gills from the Small treatment at $24 \mathrm{~h}$ were too degraded for a viable parasite count. 


\subsection{Mortality}

After $5 \mathrm{~h}$ of infestation by the parasite A. ocellatum, both treatments had a white seabream mortality of $8.3 \%$, which reached $100 \%$ in the Small treatment and $33.3 \%$ in the Big treatment after $24 \mathrm{~h}$ of infestation.

\subsection{Histopathological Analysis}

In the histological analysis of gills, several differences were observed between Small and Big treatments when white seabream were infested with A. ocellatum. The types of lesions observed in the gills of white seabream are represented in Figure 2.

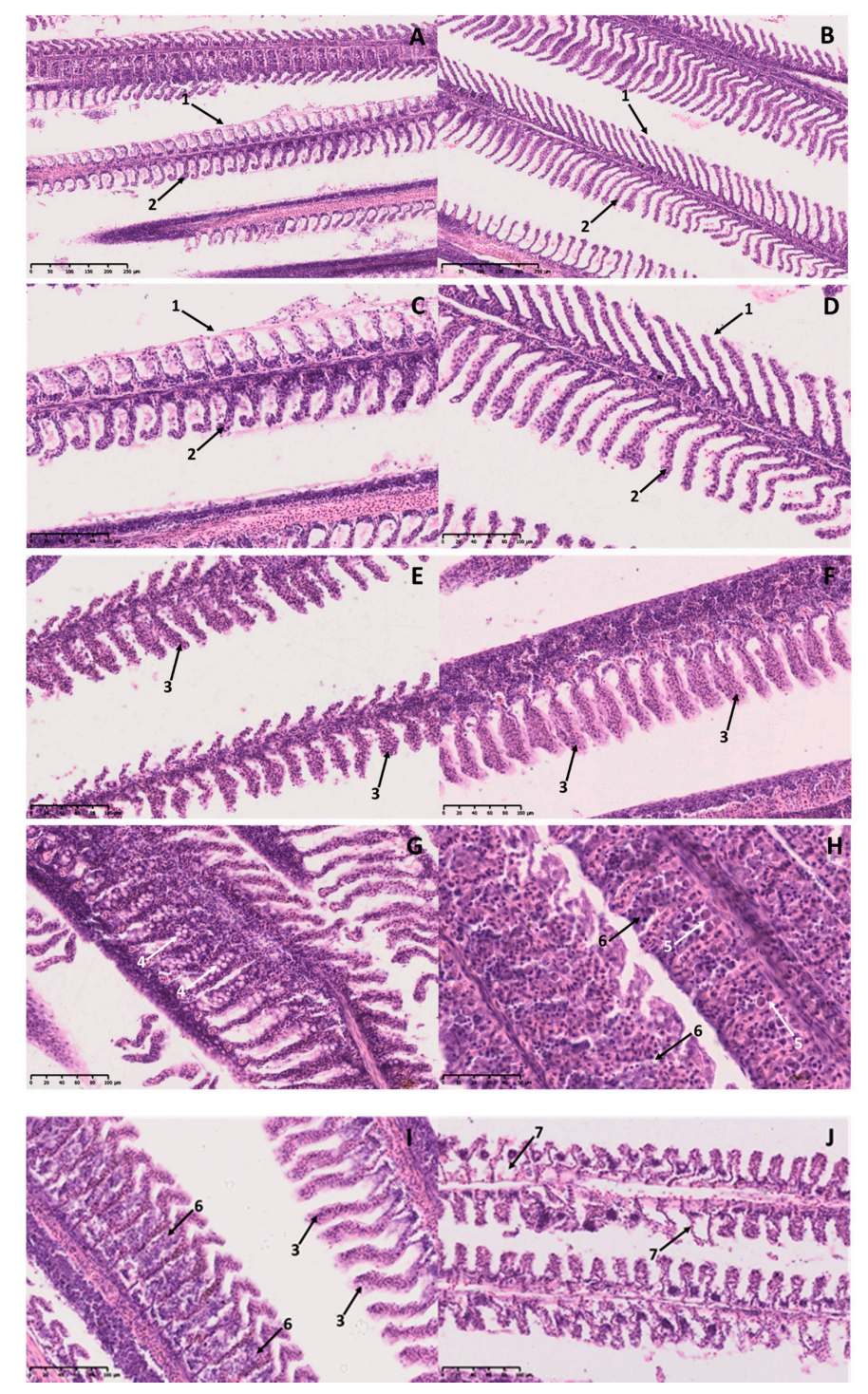

Figure 2. Histological section of hematoxylin-eosin (H\&E) stained gills from white seabream (D. sargus) during an A. ocellatum infestation. (A) $(100 \times)$ and (B) $(200 \times)$ represent the Small and (C) $(100 \times)$ and (D) $(200 \times)$ represent the Big treatments at $0 \mathrm{~h}$, with normal gills (1-primary lamella; 2 - secondary lamella); (E) $(200 \times)$ and (G) $(200 \times)$ represent the Small and (F) $(200 \times)$ and $(\mathbf{H})(400 \times)$ represent the Big treatments at $5 \mathrm{~h}$ of infestation. A.-ocellatum-infested fish gills with several histopathological alterations: hyperplasia of the lamellar epithelium (3), vacuolization (4), mucus cells (5), and fusion of secondary lamellae (6); (I) $(200 \times)$ and (J) (200×) images represent A.-ocellatum-infested fish gills of the Big treatment after $24 \mathrm{~h}$ of infestation, with several histopathological alterations: hyperplasia of the lamellar epithelium (3), fusion of secondary lamellae (6), and necrosis (7). 
The images of Figure 2 show that $A$. ocellatum infestation led to histopathological alterations such as hyperplasia and vacuolization of the lamellar epithelium and secondary lamellae fusion.

We observed that there were differences in the type of histopathological alterations between treatments $5 \mathrm{~h}$ after treatment. Gills of the Small treatment presented hyperplasia and vacuolization of the lamellar epithelium. However, gills of the Big treatment presented hyperplasia of the lamellar epithelium, an increase of mucus cells, and fusion of secondary lamellae, which culminated in gill necrosis for this treatment at $24 \mathrm{~h}$ of $A$. ocellatum infestation. The gills from the Small treatment at $24 \mathrm{~h}$ were too degraded for histopathological analysis.

\subsection{Stress Indicators}

The variations of the cortisol, glucose, lactate, and total protein levels in white seabream exposed to an A. ocellatum outbreak are presented in Figure 3.

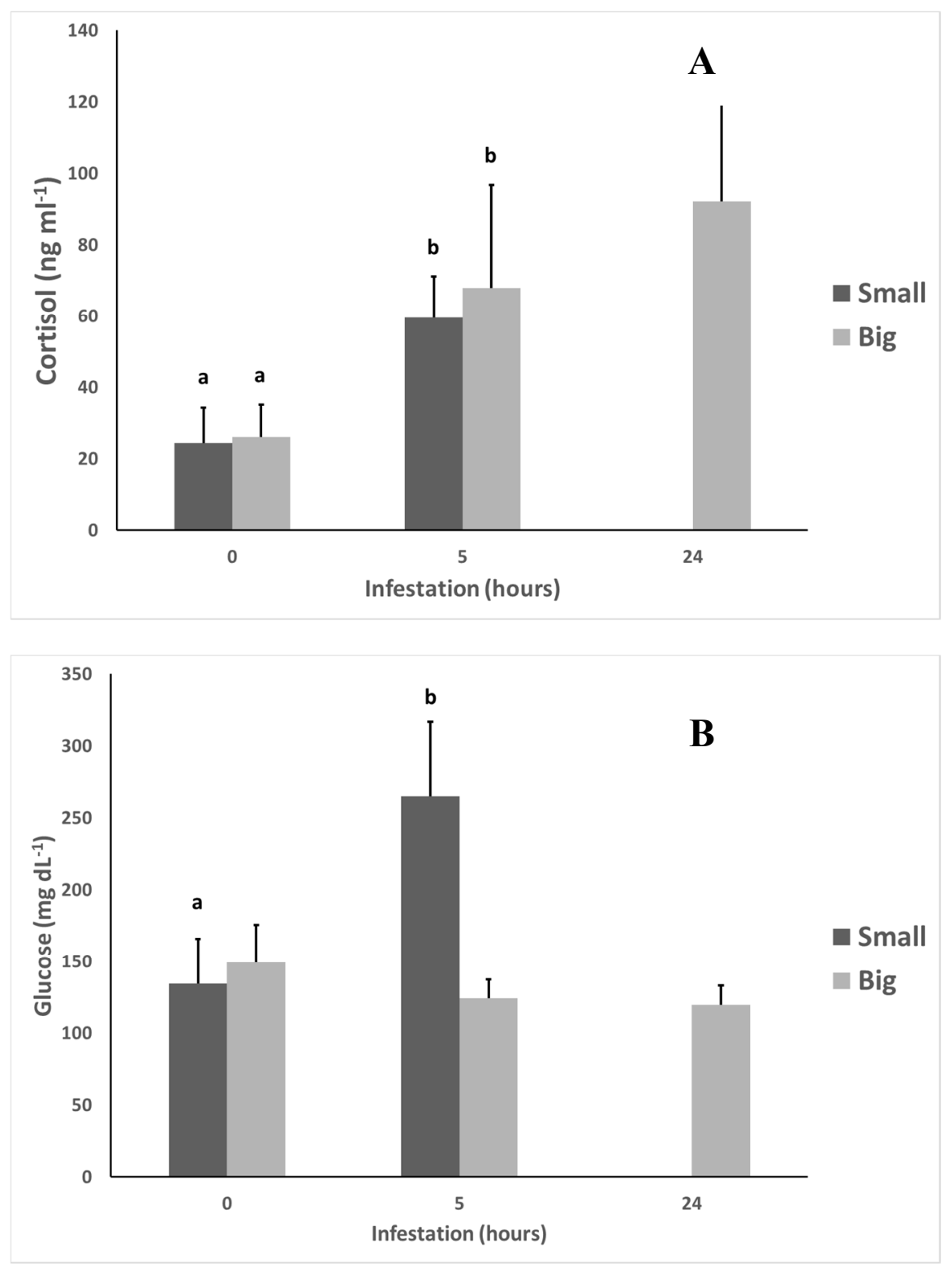

Figure 3. Cont. 

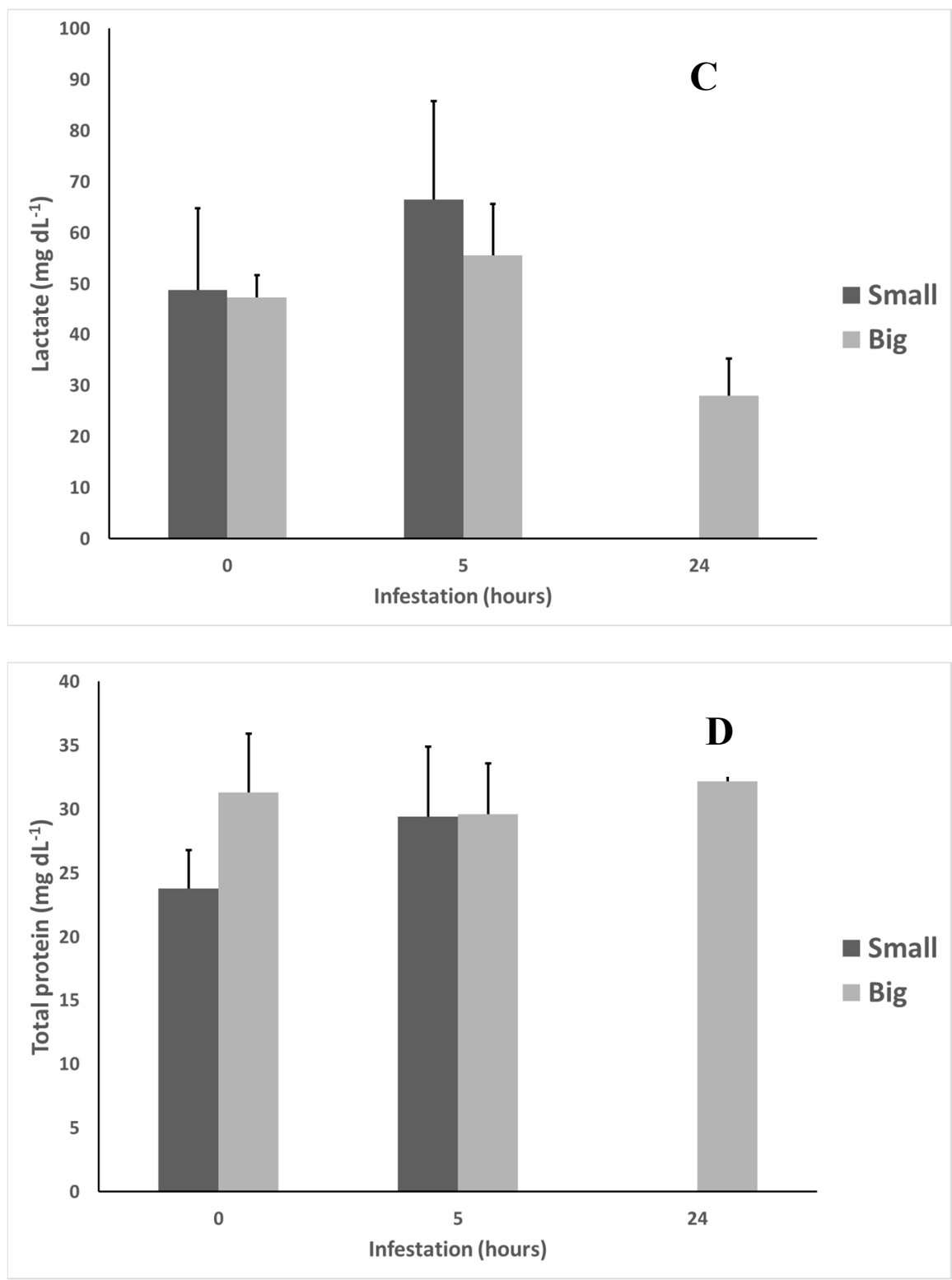

Figure 3. White seabream (D. sargus) cortisol (A), glucose (B), lactate (C), and total protein (D) levels in Small and Big treatments during an A. ocellatum infestation $(\mathrm{N}=12$ at $0 \mathrm{~h}$ after infestation for both treatments, $\mathrm{N}=11$ at $5 \mathrm{~h}$ after infestation for both treatments, $\mathrm{N}=0$ for Small treatment, and $\mathrm{N}=8$ for Big treatment at $24 \mathrm{~h}$ after infestation. Error bars = standard deviation). Significant statistical differences between treatments $(p<0.05)$ correspond to a and $\mathrm{b}$ letters.

We can observe that there were significant differences $(p<0.05)$ in the cortisol levels between fish from 0 to $5 \mathrm{~h}$ after infestation in both treatments. The Big treatment also presented significant differences $(p<0.05)$ in glucose levels between 0 and $5 \mathrm{~h}$ after infestation.

Lactate and total protein did not present any statistically significant differences $(p<0.05)$ between treatments or along the time of the experiment.

\subsection{Hematological Analysis}

The results of the different hematological indicators analyzed are shown in Table 1. 
Table 1. Hematological indicators in Small and Big treatments during an A. ocellatum infestation on white seabream (D. sargus) at 0,5 , and $24 \mathrm{~h}$ after infestation $(\mathrm{N}=12$ at $0 \mathrm{~h}$ after infestation for both treatments, $\mathrm{N}=11$ at $5 \mathrm{~h}$ after infestation for both treatments, $\mathrm{N}=0$ for Small treatment, and $\mathrm{N}=$ 8 for Big treatment at $24 \mathrm{~h}$ after infestation. Error bars = standard deviation). Significant statistical differences between treatments $(p<0.05)$ correspond to a and $\mathrm{b}$ letters.

\begin{tabular}{|c|c|c|c|c|c|c|}
\hline \multirow{2}{*}{$\begin{array}{l}\text { Hematological } \\
\text { Indicators }\end{array}$} & \multicolumn{3}{|c|}{ Small } & \multicolumn{3}{|c|}{ Big } \\
\hline & 0 & 5 & 24 & 0 & 5 & 24 \\
\hline Hct $(\% \pm \mathrm{SD})$ & $29.7 \pm 5.90$ & $34.5 \pm 6.47$ & NA & $31.2 \pm 3.74$ & $32.5 \pm 3.80$ & $30.4 \pm 4.80$ \\
\hline $\begin{array}{c}\text { Hemoglobin } \\
\left(\mathrm{g} \mathrm{dL}^{-1} \pm \mathrm{SD}\right)\end{array}$ & $5.24 \pm 0.85$ & $5.38 \pm 1.21$ & NA & $6.39 \pm 0.74$ & $6.93 \pm 0.82$ & $6.42 \pm 0.78$ \\
\hline $\mathrm{RBC}(\% \pm \mathrm{SD})$ & $99.9 \pm 1.38$ & $99.9 \pm 0.54$ & NA & $99.3 \pm 1.30$ & $99.6 \pm 1.57$ & $99.6 \pm 1.52$ \\
\hline $\mathrm{WBC}(\% \pm \mathrm{SD})$ & $\begin{array}{c}0.081 \pm \\
0.030^{\mathrm{a}}\end{array}$ & $\begin{array}{l}0.034 \pm \\
0.014^{\mathrm{b}}\end{array}$ & NA & $\begin{array}{c}0.703 \pm 0.151 \\
\mathrm{a}\end{array}$ & $\begin{array}{l}0.422 \pm \\
0.082^{b}\end{array}$ & $0.430 \underset{\mathrm{b}}{ \pm} 0.141$ \\
\hline $\operatorname{MCV}(f l \pm S D)$ & $73.6 \pm 1.46$ & $75.1 \pm 1.41$ & NA & $71.4 \pm 1.47^{\mathrm{a}}$ & $80.0 \pm 1.87^{b}$ & $82.5 \pm 1.79^{b}$ \\
\hline $\mathrm{MCH}(\mathrm{pg} \pm \mathrm{SD})$ & $13.0 \pm 2.11$ & $11.7 \pm 2.64$ & NA & $14.6 \pm 1.48$ & $17.0 \pm 2.01$ & $17.3 \pm 2.11$ \\
\hline $\begin{array}{c}\mathrm{MCHC}(\mathrm{gHb} \\
\left.100 \mathrm{~mL}^{-1} \pm \mathrm{SD}\right)\end{array}$ & $1.76 \pm 0.29$ & $1.56 \pm 0.35$ & NA & $2.05 \pm 0.21$ & $2.13 \pm 0.25$ & $2.10 \pm 0.26$ \\
\hline
\end{tabular}

*Hct-Hematocrit; RBC—Red Blood Cell count; WBC—White Blood Cell count; MCV—Mean Corpuscular Volume; $\mathrm{MCH}-$ Mean Corpuscular Hemoglobin; MCHC—Mean Corpuscular Hemoglobin Concentration; NA—sample not available due to fish death.

Hematocrit (Hct), hemoglobin, and red blood cells (RBC) did not present any statistical differences $(p<0.05)$ between Small and Big white seabream during the experiment, even if there was a tendency for an increase of this values over time. Mean corpuscular hemoglobin $(\mathrm{MCH})$ and mean corpuscular hemoglobin concentration (MCHC) also did not present any statistical differences $(p<0.05)$ between treatments.

However, we observed statistical differences $(p<0.05)$ in white blood cell $(\mathrm{WBC})$ values between treatments, with a lower percentage of WBC in the Small treatment. There were also statistical differences $(p<0.05)$ between 0 and $5 \mathrm{~h}$ after infestation in both treatments, with a decrease in the percentage of WBC over time.

For mean corpuscular volume (MCV) values, there were statistical differences $(p<0.05)$ in the Big treatment between 0 and $5 \mathrm{~h}$ after infestation, with an increase in MCV values over the time.

\section{Discussion}

Amyloodiniosis causes mortality mainly due to anoxia, osmoregulatory impairment, and secondary microbial infections due to severe epithelial damage [9,31]. This can trigger several physiological responses, as seen for gilthead seabream (Sparus aurata) [41], European sea bass (Dicentrarchus labrax) [39], and yellowtail (Seriola dorsalis) [43]. However, for white seabream, there are no references about physiological responses to $A$. ocellatum infestations.

The gill wet mount observation revealed that the gills in both treatments (Small and Big) did not have any parasite colonization at the beginning of the experiment, which confirms the absence of parasitological contamination in the used white seabream. It also demonstrated that at 5 and $24 \mathrm{~h}$ after infestation, there was A. ocellatum dinospore fixation and trophont development in both treatments.

The histopathological analysis of the white seabream gills revealed an increase in some histopathological lesions, such as hyperplasia with vacuolization, lamellar fusion, and necrosis. This agrees with the lesions reported for several fish species such as cobia (Rachycentron canadum) [40], porkfish (Anisotremus virginicus) [45], gilthead seabream [42], yellowtail [43], Senegalese sole (Solea senegalensis) [46], meagre (Argyrosomus regius) [47], silver pompano (Trachinotus blochii) [48], and European sea bass [38] for infestation of A. ocellatum. However, there were some differences in the type of histopathological lesions over time. Small treatment gills presented hyperplasia and 
vacuolization of the lamellar epithelium, and Big treatment gills presented hyperplasia of the lamellar epithelium, an increase in mucus cells (which was confirmed by the observation of great quantities of mucus in the gills for this treatment on the gill wet mount observations), and fusion of secondary lamellae at $5 \mathrm{~h}$ after infestation. The vacuolization of gill tissue observed at $5 \mathrm{~h}$ of infestation in the Small treatment is usually associated with detachment of the respiratory epithelium and necrosis [31], which can explain the $100 \%$ mortality observed at $24 \mathrm{~h}$ after infestation for this treatment. The increase in mucus cells observed at $5 \mathrm{~h}$ of infestation for the Big treatment corresponded to a gill mucosa-associated lymphoid tissue (MALT) mechanism of defense used by fish as a general response to ectoparasites [49-51], which can also lead to gill dysfunction due to excess mucus production [43]. This could explain the gill necrosis observed at $24 \mathrm{~h}$ of infestation for the Big treatment as well as the lower mortality rate in comparison with the Small treatment. The absence of an increase of mucus cells observed at $5 \mathrm{~h}$ of infestation for the Small treatment may be due to a certain immaturity of the MALT system in younger fish [49].

As natural stressors, parasites can trigger several stress responses in fish. One of the most used indicators for parasitologically induced stress response is cortisol [52]. In this experiment, a statistically significant $(p<0.05)$ higher concentration of cortisol in the fish was observed for the two treatments at $5 \mathrm{~h}$ of infestation and was maintained at $24 \mathrm{~h}$ of infestation in the Big treatment. This agrees with the cortisol levels reported in gilthead seabream and sea bass exposed to A. ocellatum $[39,41]$ and is within the range of cortisol values reported for stressed white seabream [53].

As a consequence, cortisol can induce higher concentrations of glucose caused by extended glycogenolysis and gluconeogenesis through the degradation of glycogen [54]. In this experiment, we did find statistical differences in glucose levels between 0 and $5 \mathrm{~h}$ of infestation for the Big treatment but not for the Small treatment. The glucose values were within the range of glucose values reported for white seabream $[55,56]$. The statistical difference observed in glucose levels in the Big treatment at $5 \mathrm{~h}$ after infestation are in agreement with the data observed for yellowtail infested with A. ocellatum [43] and could be a consequence of lipid storage usage for energy expenditure on gill mucus production and osmoregulation [39]. However, the absence of statistical differences in glucose levels between 0 and $5 \mathrm{~h}$ of infestation in the Small treatment is puzzling, even if it is in agreement with glucose levels observed in European seabass infested with $A$. ocellatum, which suggests a possible inhibition of the glycogenolysis and gluconeogenesis pathways in the liver by A. ocellatum [39]. This disparity of response between the two treatments could also be related to fish size [39].

The lactate values observed in this experiment were within the range of values reported for white seabream [55]. The absence of statistical differences in both treatments for lactate levels is not in agreement with the differences observed in other studies with fish parasites [57]. However, there was a tendency for a high level of lactate at $5 \mathrm{~h}$ after infestation. This could be due to the role of lactate as a response to anoxia due to severe gill epithelial damage by A. ocellatum $[9,31]$ acting in hypoxia signaling and collagen deposition processes. This also explains the tendency of higher levels of lactate in the Small treatment at $5 \mathrm{~h}$ of infestation, proportional to the gill lesions observed in the histopathological analysis for this treatment.

There were no statistical differences in both treatments for total protein levels. This is in agreement with the absence of statistical differences in total protein levels observed for gilthead seabream [42]. This could be due to the consequences of high cortisol levels, which control the blood osmolality and $\mathrm{pH}$ by regulating the balance of blood potassium and sodium ions coming from the higher production of other metabolites and proteins in response to stress [58].

In this experiment, hematological responses showed that Hct values were within the range of values expected for white seabream [59] and they were not statistically different between treatments. This agrees with the data observed for gilthead seabream in an infestation with A. ocellatum [41].

The results obtained for hemoglobin and RBC showed no statistical differences between treatments. This does not agree with the hemoglobin and RBC data observed in yellowtail infested with A. ocellatum [43]. However, the results obtained for the hemoglobin and RBC analysis followed 
a pattern similar to Hct, which is in agreement with Horton and Okamura's [60] observations for infested fishes.

The WBC profile can undergo significant changes during fish disease outbreaks and is thus an excellent indicator of immune responses. A significant decrease in WBC was observed in both treatments at $5 \mathrm{~h}$ of infestation, indicating a possible inhibition of the immune system due to high levels of cortisol [61]. This is in agreement with the data observed for gilthead seabream infested with A. ocellatum [41] and could be also associated with a possible mechanism of innate immune system evasion by this parasite [50]. Further studies are necessary to better evaluate the response of white seabream to an $A$. ocellatum infestation.

MCV showed an increasing tendency but without any statistical differences in the Small treatment, but there were statistical differences in the Big treatment between 0 and $5 \mathrm{~h}$ after infestation, with an increase in $\mathrm{MCV}$ values over time. This is in agreement with data obtained for this index in parasitic infections [62]. The absence of MCH and MCHC is also in agreement with the previous data.

When we look at all the obtained results, we can observe that the age of white seabream seems to affect the host response to an A. ocellatum infestation. One possible interpretation of the results is presented on Figure 4.
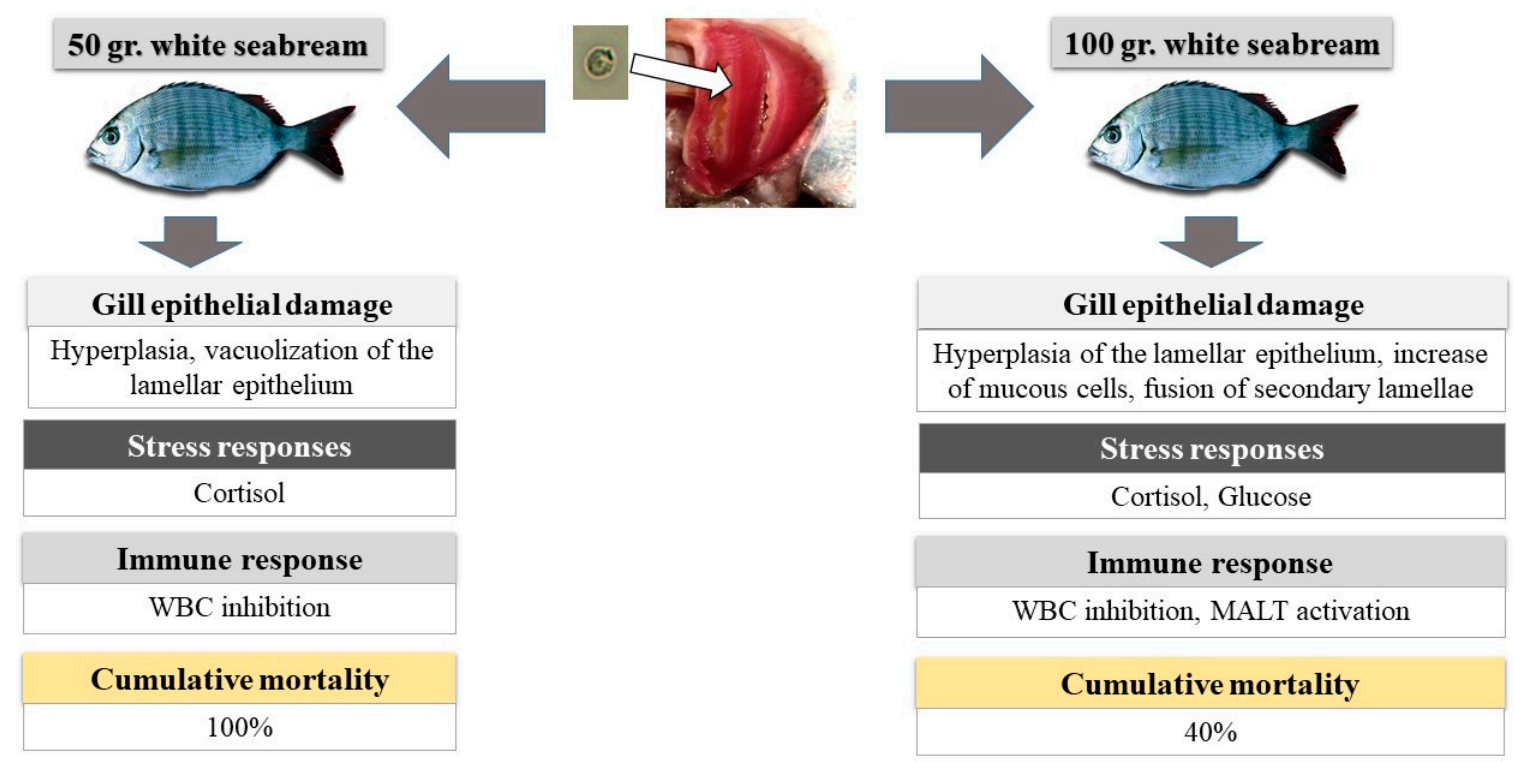

Figure 4. Possible interpretation of the results obtained from the stress, hematological, and histopathological analysis of Small (50 $\pm 5.1 \mathrm{~g}$, age: 273 days after eclosion (DAE)) and Big (101.3 \pm 10.4 g, age: 571 DAE) white seabream (D. sargus) during an A. ocellatum infestation.

So, when A. ocellatum dinospores reached the gill and started the fixation and transformation into trophonts, both Small and Big white seabream began to present lesions in gill tissue which increased over time. However, these were more severe in the Small treatment, possibly due to the nonactivation of the MALT defense system, which was present in the Big treatment (increase in gill mucus cells). This triggered a primary stress response in both treatments (cortisol), with a secondary stress response (glucose) in the Big treatment. However, the absence of glucose and lactate response in the Small treatment indicates a possible inhibition of the glycogenolysis and gluconeogenesis pathways in the liver in the Small treatment. The primary stress response to A. ocellatum also inhibited the WBC immune response in both treatments. These differences in the response to an $A$. ocellatum outbreak by the Small and Big treatments may explain the differences in mortality $24 \mathrm{~h}$ after infestation.

The findings of this paper highlight the necessity of considering fish age when designing vigilance plans (which are designed nowadays mainly taking into account the water temperature) and determining treatment actions during an A. ocellatum infestation. In this way, younger fish will 
need to have a stricter vigilance plan, with short ectoparasitological sampling periods and mitigation measures and treatment application at the first $A$. ocellatum trophont detection, to reduce fish stress and mortality resulting from amyloodiniosis. Older fish could continue to have a less strict vigilance plan, with less frequent ectoparasitological sampling periods and application of mitigation measures at lower infestations of $A$. ocellatum, and treatment application only after A. ocellatum trophont numbers reach a certain threshold, which should be determined by taking into account the water temperature of the tank.

\section{Materials and Methods}

\subsection{Fish Culture Conditions}

White seabream juveniles were reared at EPPO-IPMA (Aquaculture Research Centre, National Institute for the Sea and Atmosphere, Olhão, Portugal) and originated from a wild broodstock. After hatching, fish were reared following the protocol used in EPPO-IPMA for this species [63].

Two sets of 36 individuals, one with an average total weight of $50 \pm 5.1 \mathrm{~g}$ and an age of 273 days after eclosion (DAE) and the other with an average total weight $101.3 \pm 10.4 \mathrm{~g}$ and an age of $571 \mathrm{DAE}$, with no history of ectoparasites and no incidence of malformations, were selected. The fish were kept in two separate $1.5-\mathrm{m}^{3}$ tanks according to their weight (36 per tank) with a $14 \mathrm{~h}$ light $/ 10 \mathrm{~h}$ dark photoperiod (photophase from 6:00 a.m. to 8:00 p.m.). Water temperature was $20 \pm 1{ }^{\circ} \mathrm{C}$ and water salinity was $37.5 \mathrm{psu}$. The fish were full-fed with commercial feed three times a day until satiation.

\subsection{Preparation of A. Ocellatum Infection Tanks}

Eighteen 80-L rectangular plastic tanks were infested with 1000-1200 A. ocellatum tomonts, obtained from an induced outbreak according to the methodology described in [42], and then incubated until reaching an average of 8000 dinospores $/ \mathrm{mL}$ to maximize the stress response [41]. The water temperature was maintained at $24 \pm 0.2{ }^{\circ} \mathrm{C}, 36.5 \mathrm{psu}$ of salinity, and $100 \%$ dissolved oxygen in closed seawater systems, artificial aeration, and a $14 \mathrm{~h}$ light/ $10 \mathrm{~h}$ dark photoperiod. To avoid differences between tanks, the water from the tanks were mixed before fish were introduced to ensure the parasite load was equal in every tank.

\subsection{Experimental Design}

Fish were fasted for $24 \mathrm{~h}$ prior to the experiment. Four fish $(\mathrm{N}=4)$ were measured, weighed, and then transferred to each $80 \mathrm{~L}$ tank (Small treatment-white seabream weighing $50 \pm 5.1 \mathrm{~g}$, and Big treatment-white seabream weighing $101.3 \pm 10.4 \mathrm{~g}$ ). Each treatment had tanks in triplicate for all the sampling points. Fish were sampled at 5 and $24 \mathrm{~h}$ after the beginning of the experiment.

Mortality at each point of sampling was also registered, and dead fish were withdrawn from the tanks before fish sampling.

\subsection{Sampling Protocol}

Twelve fish per treatment were sampled in the beginning $(0 \mathrm{~h})$ of the experiment. At 5 and 24 $\mathrm{h}$ of the experiment, all the surviving fish in each treatment were sampled, prioritizing the most moribund fish, according to their behavior [1]. Fish that presented erratic and slower swimming movements, fish aggregation near the aerators and water line, accelerated opercular and mouth opening movements, or reddish marks on the skin were sampled first.

After sedation with 800 ppm of 2-phenoxyethanol [64], blood was withdrawn from the caudal vein with a $1 \mathrm{~mL}$ heparinized syringe. Collection of blood samples $(1 \mathrm{~mL}$ of blood per fish, on average) was completed within 3 min after capturing the fish to minimize the effects of handling on stress parameters. The collected blood from each fish was divided in two aliquots. One of the aliquots was immediately frozen at $-80^{\circ} \mathrm{C}$ for posterior analyses. The other blood aliquot was used for hematological analysis. 
After blood collection, the fish was sacrificed with an overdose of 2-phenoxyethanol, according with the EU Directive 2010/63/EU for animal experimentation.

Plasma was separated from cells by centrifugation (10 $\mathrm{min}, 5000 \times g$, room temperature), snap-frozen in liquid nitrogen, and stored at $-80{ }^{\circ} \mathrm{C}$ until analysis of osmolarity, $\mathrm{pH}$, hormonal (cortisol), and metabolic (glucose, lactate, and protein concentrations) parameters.

Then, the parasite burden was evaluated by microscopic observation of a wet mount of the first two branchial arches from fish killed by anesthetic overdose with 2-phenoxyethanol [41] from each treatment at all sampling points.

\subsection{Histopathological Analysis}

For histological analysis, we collected the first gill from all the fishes from each tank ( $\mathrm{N}=12$ per treatment). Following fixation in Davidson's solution ( $\mathrm{pH}$ 7.2) for two days, tissues were transferred to $70 \%$ ethanol. The tissues were processed in an automatic tissue processor Leica TP 1020 and included in paraffin wax block. Sections that were 5-nm thick were cut with a microtome slide Model Leica $5 \mathrm{M} 2000 \mathrm{R}$ and stained with hematoxylin-eosin (H\&E) according to the procedure described in [65]. Gill tissue was examined under a Nikon H550S microscope using bright-field illumination for the presence of A. ocellatum and possible pathological changes. Selected gill tissues were then scanned in a Hamamatsu Nano Zoomer Digital Pathology, and images were taken and processed using NDP View 2 software.

\subsection{Stress Indicator Analysis}

Plasma glucose and lactate levels were measured using commercial kits from Spinreact (Glucose-HK Ref. 1001200; Lactate Ref. 1001330) adapted to 96-well microplates. Plasma proteins were determined in diluted plasma samples 1:5 (v/v) with the QCA Total Proteins kit (Química Clínica Aplicada S.A., Barcelona, Spain). Plasma cortisol levels were quantified by an ELISA kit (Cortisol ELISA kit, IBL) modified and adapted to fish [66]. Cortisol was extracted from $20 \mu \mathrm{L}$ of plasma in $200 \mu \mathrm{L}$ of diethyl ether. The lower limit of detection ( $81 \%$ binding) was $0.1 \mathrm{ng} \mathrm{mL}^{-1}$ plasma. All the samples were examined in duplicate and analyzed on a microplate reader (Multiskan GO, Thermo Scientific).

\subsection{Hematological Analysis}

Hct determination was performed as described by Soares et al. [67]. In summary, a blood sample portion was transferred to nonheparinized microhematocrit tubes and centrifuged at $5000 \times g$ for $5 \mathrm{~min}$ with a hematocrit centrifuge (EBA 21 Hettich) to determine the hematocrit value. The determination of hematocrit was calculated as the percentage of red blood cells present in the amount of blood collected.

Total RBC and WBC were counted from blood dilutions using a hemocytometer.

Hemoglobin ( $\mathrm{Hgb}$ ) determination was performed using a commercial kit (1001230, Spinreact) based on the Drabkin colorimetric principle. All samples were examined in duplicate and analyzed on a microplate reader at $540 \mathrm{~nm}$ (Multiskan GO, Thermo Scientific) [68].

$\mathrm{MCV}, \mathrm{MCH}$, and MCHC were calculated with the formula described by Radu et al. [69].

\subsection{Statistical Analysis}

For group comparisons, normality was assessed using the Shapiro-Wilk test, while the homogeneity of variance was assessed using Bartlett's test. If the data were parametric, nested ANOVA followed by Tukey's test was done to detect differences between Small and Big fish. Statistical significance was accepted at $p<0.05$. These statistical tests were made using R studio (version 1.0.153). Values are expressed as mean \pm SD. 


\section{Conclusions}

We can conclude that the age of white seabream affects the response to an A. ocellatum infestation, especially at stress and histopathological levels, since smaller and younger fish seemed to have a more immature MALT defense system, and the stress reaction to the parasite seemed to be more acute. This study demonstrates that age is an influential factor in the response to an A. ocellatum infestation in white seabream, especially at stress and histopathological levels, and elucidates the need to take into account the size and age of the fish in the development and establishment of adequate mitigating measures and treatment protocols for amyloodiniosis. We recommend the establishment of a stricter vigilance protocol with scheduled ectoparasitological samples for younger fish, since they are more susceptible to an A. ocellatum outbreak. This will allow for detection of the parasitosis at an early stage of development and quicker treatment, which will avoid high mortality levels and high levels of fish stress.

Author Contributions: M.M.: Conceptualization, Methodology, Formal Analysis, Investigation, Writing-Original Draft, Visualization. A.C.-S.: Resources, Writing-Review and Editing. M.B.: Resources, Writing-Review and Editing. P.P.-F.: Project Administration, Funding Acquisition. F.S.: Conceptualization, Validation, Writing-Review and Editing, Supervision.

Funding: This study was funded by Projects DIVERSIAQUA (Mar2020 16-02-01-FMP-0066) and SAUDE\&AQUA (Mar2020 02.05.01-FEAMP-0009). This study also received Portuguese national funds from FCT-Foundation for Science and Technology through project UID/Multi/04326/2019.

Acknowledgments: Márcio Moreira has a PhD grant from FCT (SFRH/BD/118601/2016). We would like to thank Janine Sieben for her help in editing the English language of the manuscript.

Conflicts of Interest: The authors declare no conflict of interests and the funders had no role in the design of the study; in the collection, analyses, or interpretation of data; in the writing of the manuscript; or in the decision to publish the results.

\section{References}

1. Soares, F.; Quental Ferreira, H.; Cunha, E.; Pousão-Ferreira, P. Occurrence of Amyloodinium ocellatum in aquaculture fish production: A serious problem in semi-intensive earthen ponds. Aquac. Eur. 2011, 36, $13-16$.

2. Paperna, I.; Ross, B.; Colorni, A.; Colorni, B. Diseases of Marine Fish Cultured in Eilat Mariculture Project Based at the Gulf of Aqaba, Red Sea; 92-5-000964-X; FAO: Rome, Italy, 1980; pp. 29-32.

3. Landsberg, J.H.; Steidinger, K.A.; Blakesley, B.A.; Zondervan, R.L. Scanning Electron-Microscope Study of Dinospores of Amyloodinium cf Ocellatum, a Pathogenic Dinoflagellate Parasite of Marine Fish, and Comments on Its Relationship to the Peridiniales. Dis. Aquat. Org. 1994, 20, 23-32. [CrossRef]

4. Cruz-Lacierda, E.R.; Maeno, Y.; Pineda, A.J.T.; Matey, V.E. Mass mortality of hatchery-reared milkfish (Chanos chanos) and mangrove red snapper (Lutjanus argentimaculatus) caused by Amyloodinium ocellatum (Dinoflagellida). Aquaculture 2004, 236, 85-94. [CrossRef]

5. Kuperman, B.I.; Matey, V.E. Massive infestation by Amyloodinium ocellatum (Dinoflagellida) of fish in a highly saline lake, Salton Sea, California, USA. Dis. Aquat. Org. 1999, 39, 65-73. [CrossRef] [PubMed]

6. Shinn, A.P.; Pratoomyot, J.; Bron, J.E.; Paladini, G.; Brooker, E.E.; Brooker, A.J. Economic costs of protistan and metazoan parasites to global mariculture. Parasitology 2015, 142, 196-270. [CrossRef]

7. Balcázar, J.L.; Blas, I.D.; Ruiz-Zarzuela, I.; Cunningham, D.; Vendrell, D.; Múzquiz, J.L. The role of probiotics in aquaculture. Vet. Microbiol. 2006, 114, 173-186. [CrossRef]

8. Mladineo, I. Check list of the parasitofauna in Adriatic Sea cage-reared fish. Acta Vet. 2006, 56, $285-292$. [CrossRef]

9. Lawler, A.R. Studies on Amyloodinium ocellatum (Dinoflagellata) in Mississippi Sound: Natural and Experimental Hosts. Gulf Res. Rep. 1980, 6, 403-413. [CrossRef]

10. Paperna, I. Chemical control of Amyloodinium ocellatum (Brown 1931) (Dinoflagellida) infections: In vitro tests and treatment trials with infected fishes. Aquaculture 1984, 38, 1-18. [CrossRef]

11. Fajer-Avila, E.J.; Abdo-de la Parra, I.; Aguilar-Zarate, G.; Contreras-Arce, R.; Zaldivar-Ramirez, J.; Betancourt-Lozano, M. Toxicity of formalin to bullseye puffer fish (Sphoeroides annulatus Jenyns, 1843) and its effectiveness to control ectoparasites. Aquaculture 2003, 223, 41-50. [CrossRef] 
12. Kabata, Z. Parasites and Diseases of Fish Cultured in the Tropics; Taylor \& Francis Ltd.: London, UK, 1985.

13. Virgula, J.C.; Cruz-Lacierda, E.R.; Estante, E.G.; Corre, V.L., Jr. Copper sulfate as treatment for the ectoparasite Amyloodinium ocellatum (Dinoflagellida) on milkfish (Chanos chanos) fry. Aquac. Aquar. Conserv. Legis. 2017, 10, 365-371.

14. Bessat, M.; Fadel, A. Amyloodiniosis in cultured Dicentrarchus labrax: Parasitological and molecular diagnosis, and an improved treatment protocol. Dis. Aquat. Org. 2018, 129, 41-51. [CrossRef]

15. Montgomery-Brock, D.; Sato, V.T.; Brock, J.A.; Tamaru, C.S. The application of hydrogen peroxide as a treatment for the ectoparasite Amyloodinium ocellatum (Brown 1931) on the Pacific threadfin Polydactylus sexfilis. J. World Aquac. Soc. 2001, 32, 250-254. [CrossRef]

16. Seoud, S.S.M.; Zaki, V.H.; Ahmed, G.E.; El-Khalek, N.K.A. Studies on Amyloodinium Infestation in European Seabass (Dicentrarchus labrax.) Fishes with Special Reference for Treatment. Int. J. Mar. Sci. 2017, 7. [CrossRef]

17. Oestmann, D.J.; Lewis, D.H.; Zettler, B.A. Communications: Clearance of Amyloodinium ocellatum Dinospores by Artemia salina. J. Aquat. Anim. Health 1995, 7, 257-261. [CrossRef]

18. Tahraoui, S.; Ennaffah, B.; Belattmania, Z.; Reani, A.; Sabour, B. First Report on the Occurrence and Dynamics of the Ectoparasitic Dinoflagellate Amyloodinium ocellatum in the Moroccan Atlantic Coast. Res. J. Environ. Sci. 2018, 12, 153-159.

19. Gómez, F.; Gast, R.J. Dinoflagellates Amyloodinium and Ichthyodinium (Dinophyceae), parasites of marine fishes in the South Atlantic Ocean. Dis. Aquat. Org. 2018, 131, 29-37. [CrossRef]

20. Raposo de Magalhães, C.S.F.; Cerqueira, M.A.C.; Schrama, D.; Moreira, M.J.V.; Boonanuntanasarn, S.; Rodrigues, P.M.L. A Proteomics and other Omics approach in the context of farmed fish welfare and biomarker discovery. Rev. Aquac. 2018. [CrossRef]

21. Conte, F.S. Stress and the welfare of cultured fish. Appl. Anim. Behav. Sci. 2004, 86, 205-223. [CrossRef]

22. Pavlidis, M.; Angellotti, L.; Papandroulakis, N.; Divanach, P. Evaluation of transportation procedures on water quality and fry performance in red porgy (Pagrus pagrus) fry. Aquaculture 2003, 218, 187-202. [CrossRef]

23. Conceição, L.E.C.; Aragão, C.; Dias, J.; Costas, B.; Terova, G.; Martins, C.; Tort, L. Dietary nitrogen and fish welfare. Fish Physiol. Biochem. 2012, 38, 119-141. [CrossRef]

24. Alves, R.N.; Cordeiro, O.; Silva, T.S.; Richard, N.; de Vareilles, M.; Marino, G.; Di Marco, P.; Rodrigues, P.M.; Conceição, L.E.C. Metabolic molecular indicators of chronic stress in gilthead seabream (Sparus aurata) using comparative proteomics. Aquaculture 2010, 299, 57-66. [CrossRef]

25. Cordeiro, O.; Silva, T.; Alves, R.; Costas, B.; Wulff, T.; Richard, N.; de Vareilles, M.; Conceição, L.C.; Rodrigues, P. Changes in Liver Proteome Expression of Senegalese Sole (Solea senegalensis) in Response to Repeated Handling Stress. Mar. Biotechnol. 2012, 14, 714-729. [CrossRef]

26. Baldwin, L. The effects of stocking density on fish welfare. Plymouth Stud. Sci. 2011, 4, 372-383.

27. Ashley, P.J. Fish welfare: Current issues in aquaculture. Appl. Anim. Behav. Sci. 2007, 104, 199-235. [CrossRef]

28. Wall, T. Disease and Medicines-The Welfare Implications. In Fish Welfare; Blackwell Publishing Ltd.: Oxford, UK, 2008; pp. 195-201.

29. Einarsdóttir, I.E.; Nilssen, K.J.; Iversen, M. Effects of rearing stress on Atlantic salmon (Salmo salar L.) antibody response to a non-pathogenic antigen. Aquac. Res. 2000, 31, 923-930. [CrossRef]

30. Paperna, I. Reproduction cycle and tolerance to temperature and salinity of Amyloodinium ocellatum (Brown, 1931) (Dinoflagellida). Ann. Parasitol. Hum. Comp. 1984, 59, 7-30. [CrossRef]

31. Noga, E.J. Amyloodinium ocellatum. In Fish Parasites: Pathobiology and Protection; Woo, P.T.K., Buchmann, K., Eds.; CABI Publishers: Preston, UK, 2012; pp. 19-29.

32. Kuperman, B.I.; Matey, V.E.; Hurlbert, S.H. Parasites of fish from the Salton Sea, California, USA. Hydrobiologia 2001, 466, 195-208. [CrossRef]

33. Pereira, J.C.; Abrantes, I.; Martins, I.; Barata, J.; Frias, P.; Pereira, I. Ecological and morphological features of Amyloodinium ocellatum occurrences in cultivated gilthead seabream Sparus aurata L.; A case study. Aquaculture 2011, 310, 289-297. [CrossRef]

34. Noga, E.J.; Fan, Z.; Silphaduang, U. Host site of activity and cytological effects of histone-like proteins on the parasitic dinoflagellate Amyloodinium ocellatum. Dis. Aquat. Organ. 2002, 52, 207-215. [CrossRef]

35. Colorni, A.; Ullal, A.; Heinisch, G.; Noga, E.J. Activity of the antimicrobial polypeptide piscidin 2 against fish ectoparasites. J. Fish Dis. 2008, 31, 423-432. [CrossRef]

36. Woo, P.T. Protective immunity in fish against protozoan diseases. Parassitologia 2007, 49, 185-191. [PubMed] 
37. Alvarez-Pellitero, P. Fish immunity and parasite infections: From innate immunity to immunoprophylactic prospects. Vet. Immunol. Immunopathol. 2008, 126, 171-198. [CrossRef]

38. Byadgi, O.; Beraldo, P.; Volpatti, D.; Massimo, M.; Bulfon, C.; Galeotti, M. Expression of infection-related immune response in European sea bass (Dicentrarchus labrax) during a natural outbreak from a unique dinoflagellate Amyloodinium ocellatum. Fish Shellfish Immunol. 2019, 84, 62-72. [CrossRef]

39. Nozzi, V.; Strofaldi, S.; Piquer, I.F.; Di Crescenzo, D.; Olivotto, I.; Carnevali, O. Amyloodinum ocellatum in Dicentrarchus labrax: Study of infection in salt water and freshwater aquaponics. Fish Shellfish Immunol. 2016, 57, 179-185. [CrossRef]

40. Guerra-Santos, B.; Albinati, R.C.B.; Moreira, E.L.T.; Lima, F.W.M.; de Azevedo, T.M.P.; Costa, D.S.P.; de Medeiros, S.D.C.; Lira, A.D. Parameters hematological and histopathologic alterations in cobia (Rachycentron canadum Linnaeus, 1766) com amyloodiniose. Pesq. Vet. Bras. 2012, 32, 1184-1190. [CrossRef]

41. Moreira, M.; Schrama, D.; Soares, F.; Wulff, T.; Pousão-Ferreira, P.; Rodrigues, P. Physiological responses of reared sea bream (Sparus aurata Linnaeus, 1758) to an Amyloodinium ocellatum outbreak. J. Fish Dis. 2017, 40, 1545-1560. [CrossRef] [PubMed]

42. Moreira, M.; Herrera, M.; Pousão-Ferreira, P.; Navas Triano, J.I.; Soares, F. Stress effects of amyloodiniosis in gilthead sea bream Sparus aurata. Dis. Aquat. Org. 2018, 127, 201-211. [CrossRef] [PubMed]

43. Vivanco-Aranda, M.; Del Río-Zaragoza, O.B.; Lechuga-Sandoval, C.E.; Viana, M.T.; Rombenso, A.N. Health response in yellowtail Seriola dorsalis exposed to an Amyloodinium ocellatum outbreak. Cienc. Mar. 2018, 44. [CrossRef]

44. Reyes-Becerril, M.; Ascencio-Valle, F.; Alamillo, E.; Hirono, I.; Kondo, H.; Jirapongpairoj, W.; Angulo, C. Molecular cloning and comparative responses of Toll-like receptor 22 following ligands stimulation and parasitic infection in yellowtail (Seriola lalandi). Fish Shellfish Immunol. 2015, 46, 323-333. [CrossRef] [PubMed]

45. Cheung, P.J.; Nigrelli, R.F.; Ruggieri, G.D. Oodinium ocellatum (Brown, 1931) (Dinoflagellata) in the kidney and other internal tissues of pork fish, Anisotremus virginicus (L.). J. Fish Dis. 1981, 4, 523-525. [CrossRef]

46. Yemmen, C.; Bahri, S. Seasonality of Amyloodinium ocellatum Brown 1931 (Dinophyceae) infesting the Senegalese sole Solea senegalensis from Bizerte lagoon, Tunisia. J. Fish Dis. 2017, 40, 853-857. [CrossRef]

47. Soares, F.; Quental-Ferreira, H.; Moreira, M.; Cunha, E.; Ribeiro, L.; Pousao-Ferreira, P. First report of Amyloodinium ocellatum in farmed meagre (Argyrosomus regius). Bull. Eur. Assoc. Fish Pathol. 2012, 32, 30-33.

48. Kumar, P.R.; Nazar, A.K.A.; Jayakumar, R.; Tamilmani, G.; Sakthivel, M.; Kalidas, C.; Balamurugan, V.; Sirajudeen, S.; Thiagu, R.; Gopakumar, G. Amyloodinium ocellatum infestation in the broodstock of silver pompano Trachinotus blochii (Lacepede, 1801) and its therapeutic control. Indian J. Fish. 2015, 62, 131-134.

49. Ángeles Esteban, M. An Overview of the Immunological Defenses in Fish Skin. ISRN Immunol. 2012, 2012, 853470. [CrossRef]

50. Guardiola, F.A.; Cuesta, A.; Abellán, E.; Meseguer, J.; Esteban, M.A. Comparative analysis of the humoral immunity of skin mucus from several marine teleost fish. Fish Shellfish Immunol. 2014, 40, 24-31. [CrossRef] [PubMed]

51. Paperna, I. Amyloodinium-Ocellatum (Brown, 1931) (Dinoflagellida) Infestations in Cultured Marine Fish at Eilat, Red-Sea-Epizootiology and Pathology. J. Fish Dis. 1980, 3, 363-372. [CrossRef]

52. Triki, Z.; Grutter, A.S.; Bshary, R.; Ros, A.F.H. Effects of short-term exposure to ectoparasites on fish cortisol and hematocrit levels. Mar. Biol. 2016, 163, 187. [CrossRef]

53. Olivotto, I.; Mosconi, G.; Maradonna, F.; Cardinali, M.; Carnevali, O. Diplodus sargus interrenal-pituitary response: Chemical communication in stressed fish. Gen. Comp. Endocrinol. 2002, 127, 66-70. [CrossRef]

54. Olsen, R.E.; Sundell, K.; Ringø, E.; Myklebust, R.; Hemre, G.-I.; Hansen, T.; Karlsen, Ø. The acute stress response in fed and food deprived Atlantic cod, Gadus morhua L. Aquaculture 2008, 280, 232-241. [CrossRef]

55. Magalhães, R.; Martins, N.; Martins, S.; Lopes, T.; Diáz-Rosales, P.; Pousão-Ferreira, P.; Oliva-Teles, A.; Peres, H. Is dietary taurine required for white seabream (Diplodus sargus) juveniles? Aquaculture 2019, 502, 296-302. [CrossRef]

56. Enes, P.; Peres, H.; Pousão-Ferreira, P.; Sanchez-Gurmaches, J.; Navarro, I.; Gutiérrez, J.; Oliva-Teles, A. Glycemic and insulin responses in white sea bream Diplodus sargus, after intraperitoneal administration of glucose. Fish Physiol. Biochem. 2012, 38, 645-652. [CrossRef]

57. González Gómez, M.P.; Marín Arribas, S.L.; Vargas-Chacoff, L. Stress response of Salmo salar (Linnaeus 1758) facing low abundance infestation of Caligus rogercresseyi (Boxshall \& Bravo 2000), an object in the tank, and handling. J. Fish Dis. 2016, 39, 853-865. [CrossRef] 
58. Bayne, C.J.; Gerwick, L. The acute phase response and innate immunity of fish. Dev. Comp. Immunol. 2001, 25, 725-743. [CrossRef]

59. Alvarez-Pellitero, P.; Palenzuela, O.; Sitjà-Bobadilla, A. Histopathology and cellular response in Enteromyxum leei (Myxozoa) infections of Diplodus puntazzo (Teleostei). Parasitol. Int. 2008, 57, 110-120. [CrossRef]

60. Horton, T.; Okamura, B. Post-haemorrhagic anaemia in sea bass, Dicentrarchus labrax (L.), caused by blood feeding of Ceratothoa oestroides (Isopoda: Cymothoidae). J. Fish Dis. 2003, 26, 401-406. [CrossRef]

61. Portz, D.E.; Woodley, C.M.; Cech, J.J. Stress-associated impacts of short-term holding on fishes. Rev. Fish Biol. Fish. 2006, 16, 125-170. [CrossRef]

62. Fallah, F.J.; Khara, H.; Rohi, J.D.; Sayadborani, M. Hematological parameters associated with parasitism in pike, Esox lucius caught from Anzali wetland. J. Parasit. Dis. Off. Organ Indian Soc. Parasitol. 2015, 39, 245-248. [CrossRef] [PubMed]

63. Pousão-Ferreira, P.; Gonçalves, C.; Dores, E. Larval Rearing of Four Sparidae Species; Special Publication No. 36; European Aquaculture Society: Oostende, Belgium, 2005.

64. Barata, M.; Soares, F.; Aragão, C.; Almeida, A.C.; Pousão-Ferreira, P.; Ribeiro, L. Efficiency of 2-phenoxyethanol and Clove Oil for Reducing Handling Stress in Reared Meagre, Argyrosomus regius (Pisces: Sciaenidae). J. World Aquac. Soc. 2016, 47, 82-92. [CrossRef]

65. Martoja, R.; Martoja-Pierson, M. Initiation aux techniques de l'histologie animale; Masson: Paris, France, 1967.

66. Herrera, M.; Ruiz-Jarabo, I.; Vargas-Chacoff, L.; de la Roca, E.; Mancera, J.M. Metabolic enzyme activities in relation to crowding stress in the wedge sole (Dicologoglossa cuneata). Aquac. Res. 2015, 46, 2808-2818. [CrossRef]

67. Soares, F.; Leitão, A.; Moreira, M.; de Sousa, J.T.; Almeida, A.C.; Barata, M.; Feist, S.W.; Pousão-Ferreira, P.; Ribeiro, L. Sarcoma in the thymus of juvenile meagre Argyrosomus regius reared in an intensive system. Dis. Aquat. Organ. 2012, 102, 119-127. [CrossRef] [PubMed]

68. Matias, A.C.; Ribeiro, L.; Araujo, R.L.; Pousão-Ferreira, P. Preliminary studies on haematological and plasmatic parameters in gilthead sea bream (Sparus aurata) held under day/night temperature variations. Fish Physiol. Biochem. 2017, 44, 273-282. [CrossRef] [PubMed]

69. Radu, D.; Oprea, L.; Bucur, C.; Costache, M.; Oprea, D. Characteristics of haematological parameters for carp culture and Koi (Cyprinus carpio Linneaus, 1758) reared in an intensive system. Bull. Uasum Anim. Sci. Biotechnol. 2009, 66, 336-342. 